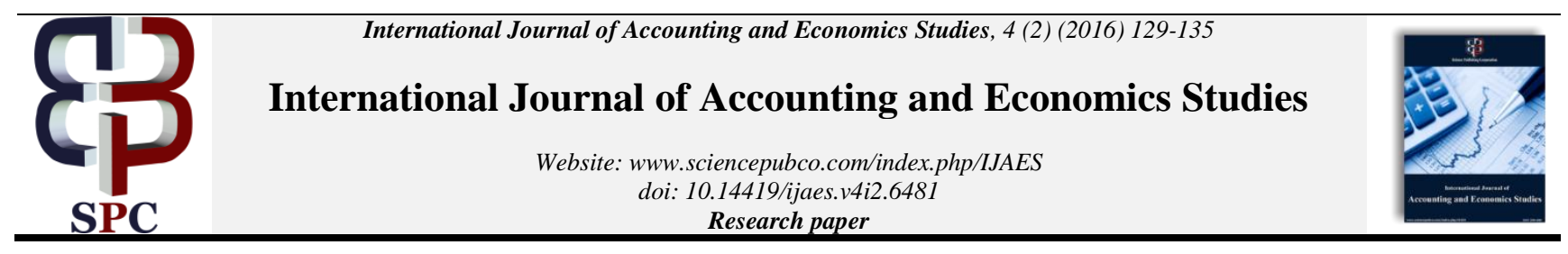

\title{
The cognitive contribution within the Tunisian venture capital funded firms
}

\author{
Houda Dziri ${ }^{1}$, Anis Jarboui ${ }^{2}$ \\ ${ }^{l}$ DziriHouda, Department of Financial and Accounting, Faculty of Economics sciences and management of Sfax, \\ University of Sfax, Tunisia \\ ${ }^{2}$ JarbouiAnis, Department of Financial and Accounting, Higher Institute of Business Administration, Universities of Sfax, Tunisia \\ *Corresponding author E-mail:houdadziri@yahoo.fr
}

\begin{abstract}
The present research work's major objective lies in investigating the scope of the venture capitalist' cognitive contribution following their financial participation in the company's capital. Conducted on a sample of 70 Tunisian venture capital funded firms, operating up the year 2015, the survey reached findings have proved to reveal well the significant impact this financial intermediation mode appears to have on kindling cognitive resources, in its association with the contractor. Noteworthy, however, is that the cognitive contribution has been discovered to be constrained, in turn, by the venture capital organization's proper ownership structure.
\end{abstract}

Keywords: Cognitive Resources; Ownership Structure; Syndication; Tunisian Companies; Venture Capital's Shares Held.

\section{Introduction}

It is worth mentioning that research works dealing with the area of governance mechanisms have been predominantly influenced by the agency theory related analysis within the context of listed firms (Barney and al., 1994; Fernandes, 2008; Belanes and Hashanah, 2010; Becher and Frye, 2011; Camuffo and Grandinetti, 2011 as well as Finet, 2012). Nevertheless the disciplinary conception of governance remains still insufficient, and appears to necessitate further investigation concerning its cognitive aspect, particularly with respect to unlisted firms (Nappet M., 2011 and Giesler, 2011). This fact seems to be also justified by the criticism directed to the traditional corporate governance model, which appears to suffer from several drawbacks or limitations (Larcker and Richardson, 2004; Jensen, 2004). Within the scope of the present study, an attempt will be made to analyze the cognitive aspect of corporate governance mainly, with respect to the venture capital funded firms. Based on the previously elaborated research work, taking financial participation of venture capitalists participation may well be accompanied an active participation with the management team thanks to their experience business, their skills and professional relationships network (Weber and Kratzer, 2013, Leete and al, 2013 and Bocken and al., 2014) enabling them to take part in the various managerial and control tasks of the firm (Davis and al., 2011; Cortez and al., 2012; Marcus and al., 2013, Bacon and al., 2013; Appelbaum and al., 2013). Consequently, the post-investment relationship between the venture capitalist and the entrepreneur should be considered as a source of interaction and success rather than an agency type of relationship (Frankeand al., 2008; Wirtz, 2011; Jengfang, 2012; Finet, 2012, Gerber and Hui, 2013). Both actors will then be strongly dependent on one another. For in, seeking the project be successful, the entrepreneur will want to cooperate with the venture capitalist (Parrich, 2010, Armstrong and al., 2014), while the venture capitalist, on seeking the achievement of significant added value in the return for capital release output should go further beyond the financial contribution towards an intervention and a contribution for the sake of more effective development of the firm funded by the mobilization of financial and human resources in a bid to meet their financial needs (Hochberg and al., 2007; Fabian and Ndofer, 2007; Burer and Wüstenhagen, 2008; Marcus and al., 2013). In this regard, and with respect to the Tunisian context, we propose to examine the cognitive contributions brought about by venture capitalist through participation in the firm's capital.

The remainder of this paper is organized as follows. Section 2 is dedicated to expose a literature review and hypotheses elaboration. As for section 3, it involves a description of the applied methodology. While section 4, depicts an evaluation of the achieved empirical results. Finally, section 5 bears the concluding remarks and paves the way for potential research perspectives.

\section{Literature review and hypotheses elabora- tion}

\subsection{The venture capitalist's cognitive contribution}

It is worth highlighting that both of the venture capitalist and executive entrepreneur's perception of investment opportunities and business evolution appear to differ noticeably. Characterized by a strong subjective dimension, it, then, results in a variety of cognitive models. Actually, the confrontation of these different models induces the appearance of conflicts between both of these partners (Richard, 1990; Desbrières, 2005 and Wirtz, 2006).

Owing to their daily contact with the production factors, the entrepreneurs/managers would enjoy specific knowledge of the firm. Yet, they do not always have the experience more do they enjoy the expertise necessary for managing the major problematic issues related to the development of the company. Still venture capitalists 
enjoy an overall knowledge of the company (Duchénaut, 1996 and Cable et Shane, 1997). Hence, the more significant this knowledge gap is, more intense the problem of knowledge asymmetry problem will be which is likely to help promote cognitive costs and conflicts. In parallel with the appearance of cognitive conflicts, the confrontation of perception and sharing of experiences and competences skills related to both parties capacity to cooperate, (Langlois and Robertson ; 1995, Pluchart, 2010 ; Bocken and al., 2014) giving rise to cognitive gains. So, cognitive conflicts are not always inconvenient, as they help enhance discussions negotiations, and could, therefore, generate new constructive ideas (Foss, 1996; Schmitt, 2008 and Berry et al., 2013).Such innovative conflicts seem to be even crucial and critically necessary for company growth and essential for the team performance (Stéphany, 2003 and Lans and al., 2014).

In the same context, and on analyzing the different contributions and advantages, the capital investor could bring about while investing the enterprise, Sapienza and al. (1994), Sheen and al (2014) and Learner and al. (2014), stress highly the latter strategic role, through joint collaboration of the other managers for the conception of their visions, by influencing the way how strategic decisions concerning strategic matters should be taken and through guiding the company's strategic choices and investment policy. The venture capitalist may also intervene at a more operational level through appealing to external consultants and consolers to fill their proper lack in matters of skills and knowledge, as well as the executive's lack regarding certain specific areas such as human resources, marketing, company environment and market (Hellman and Puri, 2002; Gerber and Hui, 2013; Bocquet and Mothe, 2013 and Bocken, 2015). Added to these contributions or inputs, is the organizational contribution maintained through the employment of skill fully experienced executives, through the new financial resources provisions, as well as through the disposition of their professional relations. Furthermore, the venture capitalist provides an informal contribution through the intervention and presence within the company, which already exhibit a signal of organizational and managerial quality as well as a guarantee for the company. Such a signal ensures easy raising of new resources for the firm. Such a guarantee is actually more important than that of companies which do not enjoy the presence of venture capitalists (Davila, 2003; Stéphany, 2003; Zhiying, 2012; Xubo, 2012; Lantz and al., 2014). As a result, the relationship between the venture capitalist and the entrepreneur / manager would rather take the form of an instructional, or apprenticeship, relationship, in which each party is considered as an acquirer of knowledge and skill. Thus, appealing to venture capital as a funding source turns out to be a simultaneous source of cognitive contributions.

A significant stake participation from the part of the venture capitalist would denote and imply financial investments as well as a time investment for an effective accompanying of the entrepreneur. Noteworthy, however, once their financial interests prove to be too weak, venture capitalists would not necessarily be motivated to maintain any kind of sharing and apprenticeship process with the entrepreneur (Daily, 2002; Siegel and al., 2011; Wood and Wright, 2010 ; Finet, 2012 ; Lamarche and al., 2012 and Rosenbush and al., 2013). The venture capitalist's participation rate influences their propensity to get involved in the firm governance firm and offer the funded firm new resources other than the financial ones. This participation would affect several specific characteristics of the funded firm. As a synthesis of the link between the venture capitalist's involvement and the financed companies performance, several empirical studies have revealed that the venture capitalist, as a medium and long term investor and partner, helps provide some surplus or contributions other than the financial one to the companies they sustain and support (Mathieu, 2003; Arthus, 2005 and Bacon and al., 2012). Hence, the following hypothesis could be advanced:

Hypothesis: The organism's financial contribution highly associated with the provision of extra cognitive resources within the financed company.

\subsection{Control variables}

The venture capitalist cognitive contribution will be controlled by the firm's development stage, during their financial intervention, measured through the company age. At advanced development stage, the firm is characterized by a remarkable amount of knowledge, which is likely to restrict it need in the venture capitalist's cognitive resources (Sapienza and al., 1996; Georgen and al., 2011 and Amess and Wright, 2012). In addition, the venture capitalist's ownership structure will also be introduced, as measured by the bank affiliate, as most of the Tunisian venture capital organisms are affiliated with bank institutions (Tunisian Association of Capital Investors). In this regard, Desbrières and Schatt (2002) have documented that the venture capitalist's ownership structure exerts an influence on their relations with entrepreneurs/ managers. Captive or semi-captive venture capitalist's raising their funds from institutional investors or business angel, look primarily to maximize their profitability for a particular risk level and structure their resources in such a way as to secure significant values, while independent capital investors, as a bank, insurance company or industrial company affiliate most often target, objectives that go beyond the financial performance of their investments, such as job creation purposes (Robbie,1992 ; Robbie and Wrigt, 1996, Hisrich and Walz, 2006 ; Bottazi, 2007 and Hellmann, Lindsey and Puri, 2008 ). As a control variable, the experience in the venture capitalist business has been considered. In fact several studies, such as those conducted by Sapienza and al. (1996) and Manigart and al. (2002) have indicated that the success of a private equity funded firm is positively correlated with the investors' experience levels. These investors are rather considered as investors of highly superior competences likely to help contribute in enhancing the company's development. In Fact, The most experienced among these capital investors usually enjoy a great capacity to assess environmental tendencies and identify the most convenient investment opportunities and financing policies (Manigart and al., 2002 and Stromberg, 2007). The venture capitalist's cognitive contribution may also be controlled through syndication, measured by the percentage of shares held by other investors than the venture capitalist. In financial terms, syndication designates the entirety of risk sharing and diversification means. In this respect, Manigart and al. (2006) attribute syndication a cognitive role. They highlight that the capital investor is not only concerned with providing financial resources or ensuring profitability of their investments, but also seek to offer the company some resources of a cognitive type likely to help further promote the company's performance and development. In this way, syndication would allow managers to acquire new skills and resources, thus, solving the knowledge asymmetry problem. In this regard, Tian (2008) has shown that firms supported by syndicated capital investors are those that have the greatest chance to be listed or floated with stock exchange, enjoy better valuation of shares on the market and record a higher performance. Finally, the entrepreneur's shareholding, measured by his percentage detained share, has been introduced as a control variable. It is expect that the higher entrepreneur's share in the company's capital is, the more aligned his preferences would be with those of the venture capitalist, and the more extended, the latter's cognitive intervention scope, would be field it will be more extensive (Gompers and Xuan, 2009).

\section{Data and methodology}

This section is devoted to discuss the empirical methodology applied for testing the already-developed hypothesis.

\subsection{Sample selection and data}

Our initial sample consists of 150 Tunisian firms funded through venture-capital organizations, operating until the year 2014. To these firms, a questionnaire has been addressed, with an introductory cover letter exposing the research theme and objective, while 
ensuring data confidentiality information. Among the sent questionnaires, only 70 responses have been received, thus reducing our sample to 70 firms.

So, our sample companies' activity sector turns out to be decomposed follows: $48.57 \%$ of the activities are dedicated to industrie goods and services, $12.85 \%$ to the informatics and Software, $8.57 \%$ to the health sector and $30 \%$ to the services.

Table1: Sampla Firms' Distribution by Activity Sector

\begin{tabular}{ll}
\hline Sector & Sample percentage \\
\hline Industriel good and services & 48.57 \\
Computering and Software & 12.85 \\
Health & 8.57 \\
Services & 30 \\
\hline
\end{tabular}

During the venture capitalist's financial intervention, $17.4 \%$ of our sample firms have beenin the seed stage (upstream creation stage for the product technological-process development prior to the marketing phase and the setting up of prototypes), $31.43 \%$ of the sample have been in the establishment phase (for product development and marketing), and $51.42 \%$ of firms have already exceeded the creation stage (towards fundingof either new production capacities, or the development of new products within the maturity and development stages, or for corporate buyouts).

Table 2: Sample Firms' Distribution by the Development Stage throughout the Venture Capitalist's Intervention

\begin{tabular}{ll}
\hline Development stage & Samplepercentage \\
\hline Seed stage & 17.14 \\
Creation or start up & 31.43 \\
Post creation & 51.42 \\
\hline
\end{tabular}

\subsection{Methodology}

For the purpose of studying the issue of the venture capitalist's cognitive contribution following participation in the firm's capital, we will proceed with the binary logistic regressions of the different variables useful for measuring the venture capitalist's cognitive contribution. The venture capital providing firm's is going to be measured by means of four dependent variables, classified in terms of two distinct categories, in respect of the cognitive contribution they might well bring about. The first category involves the venture capitalist's assistance role provided to the contracting firm via both of the following variables: "coup_support" and "orientation". As for category, it related to the venture capitalist's participative role in the company activities dynamism, thus, bearing and incurring greater risk via the two variables: "prof_relation" and "Inv_Opport".

Thus, the following logistic regression models should be estimated:

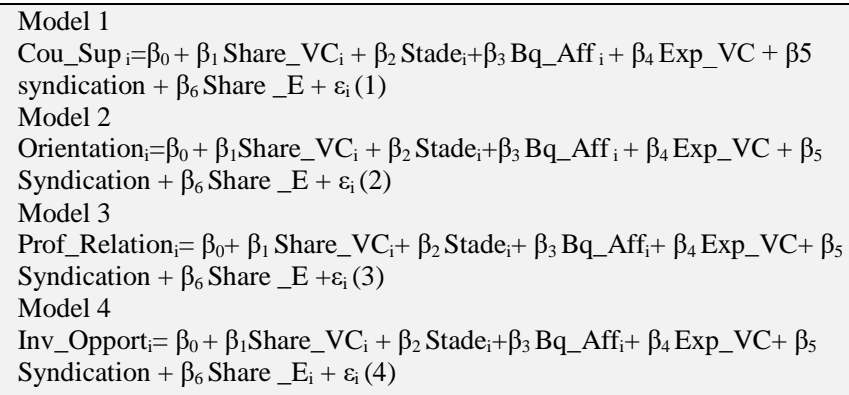

Cou_Sup= a dichotomous variable that takes value " 1 " if the venture capitalist takes part in the council and in the entrepreneur support and " 0 " otherwise, Orientation= a dichotomous variable that takes value " 1 " if the venture capitalist participates in the firm's strategic orientation choice and " 0 " otherwise, Prof_Relation= a dichotomous variable that takes value " 1 " if the venture capitalist helps in providing the entrepreneur with professional labor relations and " 0 " otherwise, Inv_Opport= a dichotomous variable that takes value " 1 " if the venture capitalist participates in creating investment opportunities and "0" otherwise, Share_VC= the percentage of shares held by the venture capitalist, Stage $=$ the firm age at the time of the venture capitalist's participation in its capital, $\mathrm{Bq}$ Aff $=$ a dichoto- mous variable that takes value " 1 " if the venture capitalist affiliated with a banking institution and " 0 " otherwise, Exp_VC= the number of experience years in the venture capital business, Syndication $=$ the percentage of shares held by investors other than the venture capitalist, Share _E= the percentage of shares held by the entrepreneur, $\beta 0=$ constant, $\beta 1 ; \beta 2 ; \beta 3$; $\beta 4 ; \beta 5 ; \beta 6=$ parameters to be estimated, $\varepsilon=$ models residue.

\section{Empirical results}

\subsection{Descriptive statistics}

Tables 3, 4 and 4 below summary the descriptive statistics relevant to both of the continuous and binary dependent and independent variables. The table illustrates the descriptive statistics concerning of a mean and standard deviation.

Regarding our study case, the venture capitalists' average participation in the sample firms' capital is equal to $34.04 \%$. During this financial intervention, the firms tend to display an average development stage, as measured by age, which seems to equal 4.47 years. Recourse to venture capital funding has been particularly undertaken the newly established firms, whose need in financial resources seems remarkably important.With respect to experience in the business, it has been discovered that venture capital specialized organisms appear to be quite young (17.86 years), denoting that the venture capital business sector is quite young in Tunisia. Against $34.04 \%$ the venture capitalist's average financial contribution, the entrepreneur's average participation in the firm's capital has been discovered to equal $32.21 \%$. Hence, it seems that there exist investors, other than the venture capitalist, that have participated in the firm's capital, which leads us to talk about the investors' syndication measured by their financial participation, which seems to be equal to $8.28 \%$, on average.

Table3: Descriptive Statistics Relevant to the Continuous Independent Variables

\begin{tabular}{lllll}
\hline & Mean & Sdt.Dev & Min & Max \\
\hline Share_VC & 34.04 & 13.21 & 3 & 43 \\
Stage & 4.47 & 1.692 & 0 & 7 \\
Exp_VC & 17.86 & 7.157 & 4 & 35 \\
Syndication & 8.28 & 6.829 & 10 & 31 \\
Share_E & 32.21 & 11.855 & 10 & 56 \\
\hline
\end{tabular}

Share $\mathrm{VC}=$ the percentage of shares held by the venture capitalist, Stage $=$ the firm age at the time of the venture capitalist's participation in its capital, Exp_VC= the number of experience years in the venture capital business, Syndication $=$ the percentage of shares held by investors other than the venture capitalist, Share _E= the percentage of shares held by the entrepreneur.

In regard of our case, it has been noticed that $58.57 \%$ among the venture capitalists who have provided support to our study sample firms appear to be affiliated with banks.

Table 4: Descriptive Statistics Relevant to the Binary Independent Variables

Takes the modality "0" (in \%) $\quad$ Takes the modality "1" (in \%)

Bq_Aff 42.85

Bq_Aff $=$ a dichotomous variable that takes value " 1 " if the venture capi-

talist affiliated with a banking institution and " 0 " otherwise.

As can be noticed, and with respect to a significant number of our sample firms, the venture capitalist acts as a council and a sustaining support for the entrepreneur ( $88.57 \%$ of total firms), as compared to $74.28 \%$ taking part in guiding the orientation of the entrepreneur's strategic choices. One, can, thus conclude that the venture capitalist's assistance and its implication in terms of the financed firm's strategic orientation turns out to be quite important. As for the latters, participation in firm dynamism, one may that he has put his proper professional relationships at the management disposal most of the firms with regard to most of the firms he funds $(67.14 \%$ of the sample). Concerning the creation of investment opportunities, however, only $41.42 \%$ of firms that have assigned such a role to venture capitalist. 
Table 5:Descriptive Statistics Relevant to the Binary Dependent Variables

\begin{tabular}{lll}
\hline & $\begin{array}{l}\text { Takes the modality "0" } \\
\text { (in \%) }\end{array}$ & $\begin{array}{l}\text { Takes the modality "1" } \\
\text { (in \%) }\end{array}$ \\
\hline Cou_Sup & 11.43 & 88.57 \\
Orientation & 25.71 & 74.28 \\
Prof_Relations & 32.85 & 67.14 \\
Inv_Opport & 58.57 & 41.42
\end{tabular}

Cou_Sup $=$ a dichotomous variable that takes value " 1 " if the venture capitalist takes part in the council and in the entrepreneur support and " 0 " otherwise, Orientation= a dichotomous variable that takes value " 1 " if the venture capitalist participates in the firm's strategic orientation choice and " 0 " otherwise, Prof Relation= a dichotomous variable that takes value " 1 " if the venture capitalist helps in providing the entrepreneur with professional labor relations and "0" otherwise, Inv Opport= a dichotomous variable that takes value " 1 " if the venture capitalist participates in creating investment opportunities and " 0 " otherwise.

\subsection{Logistic-regression analysis results}

\subsubsection{Correlation matrix and multicollinearity}

Table 6, below, illustrates the Pearson's rho correlations persisting among the logistic regression applied variables. The sample consists of 70 firms. What matters most in a regression analysis is the multicollinearity problem prevailing among the independent variables. According to Table 6, all the correlation coefficients are below 0.8 , the limit starting from which one starts to have a serious problem of multicollinearity. In addition, the variance inflation factors (VIFs) test, which also helps test the presence of collinearity among the explanatory variables, has also been implemented with regard to all cases, the VIFs are sited below two, bearing in mind that the critical value is 10 (Tabachnick and Fidell, 1996). Hence, one could well deduce the absence of any multicollinearity problems with respect to our study case.

Table 6: Pearson Correlation Matrix and Vifs

\begin{tabular}{|c|c|c|c|c|c|c|c|}
\hline $\mathrm{N}=70$ & $\begin{array}{l}\text { Share_V } \\
\text { C }\end{array}$ & $\begin{array}{l}\text { Stag } \\
\mathrm{e}\end{array}$ & $\begin{array}{l}\text { Bq } \\
\text { Aff }\end{array}$ & $\begin{array}{l}\text { Exp_V } \\
\mathrm{C} \\
\end{array}$ & $\begin{array}{l}\text { Syndica- } \\
\text { tion }\end{array}$ & $\begin{array}{l}\text { Share_ } \\
\text { E }\end{array}$ & VIF \\
\hline $\begin{array}{l}\text { Share_V } \\
\text { C }\end{array}$ & 1 & & & & & & $\begin{array}{l}1.36 \\
5\end{array}$ \\
\hline Stage & $0.2^{* *}$ & 1 & & & & & 1.08 \\
\hline $\mathrm{Bq} \_\mathrm{Aff}$ & 0.11 & $\begin{array}{l}- \\
0.00 \\
9\end{array}$ & 1 & & & & $\begin{array}{l}1.02 \\
6\end{array}$ \\
\hline Exp_VC & $0.238 * *$ & $\begin{array}{l}- \\
0.11 \\
8\end{array}$ & 0.02 & 1 & & & $\begin{array}{l}1.23 \\
9\end{array}$ \\
\hline $\begin{array}{l}\text { Syndica- } \\
\text { tion }\end{array}$ & $0.254 * *$ & $\begin{array}{l}0.05 \\
2\end{array}$ & $\begin{array}{l}0.05 \\
2\end{array}$ & $0.249 *$ & 1 & & $\begin{array}{l}1.22 \\
2\end{array}$ \\
\hline Share_E & $-0.26^{* *}$ & $\begin{array}{l}0.02 \\
2\end{array}$ & $\begin{array}{l}- \\
0.00 \\
9\end{array}$ & $-\overline{0.163 *}$ & 0.042 & 1 & $\begin{array}{l}1.09 \\
7\end{array}$ \\
\hline
\end{tabular}

Share_VC $=$ the percentage of shares held by the venture capitalist, Stage= the firm age at the time of the venture capitalist's participation in its capital, $\mathrm{Bq} \mathrm{Aff}=\mathrm{a}$ dichotomous variable that takes value " 1 " if the venture capitalist affiliated with a banking institution and " 0 " otherwise, Exp_VC= the number of experience years in the venture capital business, Syndication $=$ the percentage of shares held by investors other than the venture capitalist, Share_E= the percentage of shares held by the entrepreneur.

\subsubsection{Regression analysis}

Table 7, below illustrating the logistic regression attained results, depicts the relationship between the venture capitalist's cognitive contribution, as measured through four dependent variables, and his financial participation in the funded firm capital. The four dependent variables will be respectively introduced in the models $1,2,3$ and 4 .
Table7: Logistic Regression Results Relevant to Models 1, 2, 3 and 4

\begin{tabular}{|c|c|c|c|c|c|c|c|c|}
\hline & \multicolumn{2}{|c|}{$\begin{array}{l}\text { Model } 1 \\
\text { (DV : Cou- } \\
\text { Sup) }\end{array}$} & \multicolumn{2}{|c|}{$\begin{array}{l}\text { Model } 2 \\
\text { (DV : Orienta- } \\
\text { tion) }\end{array}$} & \multicolumn{2}{|c|}{$\begin{array}{l}\text { Model } 3 \\
\text { (DV : Prof_ } \\
\text { Relation) }\end{array}$} & \multicolumn{2}{|c|}{$\begin{array}{l}\text { Model } 4 \\
\text { (DV : } \\
\text { Inv_Opport ) }\end{array}$} \\
\hline & $\begin{array}{l}\text { Coe } \\
\text { f. }\end{array}$ & $\begin{array}{l}\text { Wald } \\
X^{2}\end{array}$ & $\begin{array}{l}\text { Coe } \\
\text { f. }\end{array}$ & $\begin{array}{l}\text { Wald } \\
X^{2}\end{array}$ & $\begin{array}{l}\text { Coe } \\
\text { f. }\end{array}$ & $\begin{array}{l}\text { Wald } \\
X^{2}\end{array}$ & $\begin{array}{l}\text { Coe } \\
\text { f. }\end{array}$ & $\begin{array}{l}\text { Wald } \\
X^{2}\end{array}$ \\
\hline \multicolumn{9}{|c|}{ Independent variables. } \\
\hline $\begin{array}{l}\text { Share } \\
\text { VC }\end{array}$ & $\begin{array}{l}0.2 \\
51\end{array}$ & $\begin{array}{l}7.624 * \\
* *\end{array}$ & $\begin{array}{l}0.1 \\
58\end{array}$ & $\begin{array}{l}5.002 \\
* *\end{array}$ & $\begin{array}{l}- \\
0.1 \\
06\end{array}$ & $3.591 *$ & $\begin{array}{l}0.3 \\
16\end{array}$ & $\begin{array}{l}13.912 \\
\text { *** }\end{array}$ \\
\hline
\end{tabular}

Control variables

\begin{tabular}{|c|c|c|c|c|c|c|c|c|}
\hline Stage & $\begin{array}{l}0.2 \\
94\end{array}$ & 2.41 & $\begin{array}{l}0.2 \\
5\end{array}$ & -0.511 & $\begin{array}{l}0.5 \\
11\end{array}$ & $5.07 * *$ & $\begin{array}{l}1.5 \\
44\end{array}$ & 1.544 \\
\hline Bq_Aff & $\begin{array}{l}- \\
1.3 \\
14\end{array}$ & 2.012 & $\begin{array}{l}- \\
2.2 \\
17\end{array}$ & 0.909 & $\begin{array}{l}0.9 \\
09\end{array}$ & 1.574 & $\begin{array}{l}- \\
0.9 \\
07\end{array}$ & $1.438^{*}$ \\
\hline $\begin{array}{l}\text { Exp_V } \\
\text { C }\end{array}$ & $\begin{array}{l}0.0 \\
23\end{array}$ & 0.192 & $\begin{array}{l}0.0 \\
78\end{array}$ & 0.091 & $\begin{array}{l}0.0 \\
91\end{array}$ & $3.626^{*}$ & $\begin{array}{l}1.1 \\
41\end{array}$ & $\begin{array}{l}6.000 * \\
* *\end{array}$ \\
\hline $\begin{array}{l}\text { Syndi- } \\
\text { cation }\end{array}$ & $\begin{array}{l}- \\
0.3 \\
24\end{array}$ & 0.781 & $\begin{array}{l}- \\
0.0 \\
12\end{array}$ & 0.1 & $\begin{array}{l}0.5 \\
56\end{array}$ & $2.797 *$ & $\begin{array}{l}0.6 \\
06\end{array}$ & $3.111 *$ \\
\hline Share_E & $\begin{array}{l}0.0 \\
63\end{array}$ & $\begin{array}{l}4.496 * \\
*\end{array}$ & $\begin{array}{l}- \\
0.0 \\
03\end{array}$ & 0.011 & $\begin{array}{l}- \\
0.0 \\
62\end{array}$ & 5.307 & $\begin{array}{l}1.2 \\
06\end{array}$ & 1.206 \\
\hline $\begin{array}{l}\text { Cons- } \\
\text { tant }\end{array}$ & $\begin{array}{l}- \\
2.6 \\
10\end{array}$ & 1.573 & $\begin{array}{l}3.2 \\
07\end{array}$ & 2.497 & $\begin{array}{l}3.4 \\
3\end{array}$ & 3.356 & $\begin{array}{l}2.4 \\
41\end{array}$ & 1.936 \\
\hline \multicolumn{2}{|c|}{ R2 Nagelkerke } & $33.6 \%$ & & $24.2 \%$ & & $36.2 \%$ & & $40.8 \%$ \\
\hline \multicolumn{2}{|c|}{ X2 Statistique } & $\begin{array}{l}18.437 \\
* * *\end{array}$ & & $\begin{array}{l}12.58 \\
7 * *\end{array}$ & & $\begin{array}{l}22.152 \\
* * *\end{array}$ & & $\begin{array}{l}24.673 \\
\text { *** }\end{array}$ \\
\hline Prob $>F$ & & 0.005 & & 0.05 & & 0.001 & & 0.000 \\
\hline
\end{tabular}

$\mathrm{DV}=$ dependant variable, Cou_Sup $=$ a dichotomous variable that takes value " 1 " if the venture capitalist takes part in the council and in the entrepreneur support and " 0 " otherwise, Orientation= a dichotomous variable that takes value " 1 " if the venture capitalist participates in the firm's strategic orientation choice and " 0 " otherwise, Prof_Relation= a dichotomous variable that takes value " 1 " if the venture capitalist helps in providing the entrepreneur with professional labor relations and " 0 " otherwise, Inv_Opport= a dichotomous variable that takes value " 1 " if the venture capitalist participates in creating investment opportunities and " 0 " otherwise, Share_VC= the percentage of shares held by the venture capitalist, Stage $=$ the firm age at the time of the venture capitalist's participation in its capital, $\mathrm{Bq} \mathrm{Aff}=\mathrm{a}$ dichotomous variable that takes value "1" if the venture capitalist affiliated with a banking institution and " 0 " otherwise, Exp_VC $=$ the number of experience years in the venture capital business, Syndication $=$ the percentage of shares held by investors other than the venture capitalist, Share _E= the percentage of shares held by the entrepreneur, *, **and *** Correlations significant at the $10 \%, 5 \%$ and $1 \%$ level.

The $\mathrm{R}^{2}$ Nagelkerke, indicates that $33.6 \%, 24.2 \%, 36.2 \%$ and $40.8 \%$ of the cognitive contribution has been explained through the venture capitalist's financial participation as well as the control variables.

An examination of the statistical tests depicted in Model 1 and Model 2 highlight well that the venture capitalist's financial participation "Share_VC" appears to have a positive effect on his cognitive contribution to the funded firm, as measured via the dependent variables "Cou_Sup" and "Orientation". The regression coefficient of the variable "Share_VC" seems to be positive and significant at the threshold of $1 \%(\beta=0.251$ in Model 1 and $\beta=$ 0.158 in model 2). This implies that the venture capitalist's financial participation has been accompanied with a cognitive contribution measured through his participation in the board council and sustain for the manager in guiding his strategic choices.

An examination of the statistical tests set out in Model 3 and Model 4 reveals well that the venture capitalist financial participation appears to have a negative effect on his cognitive contribution as measured through the dependent variables "Prof_Relation" and "Inv_Opport". The regression coefficient of the variable "Share_VC" seems to be negative and significant at both of the $10 \%$ threshold and 1\% thresholdrespectively, in Model 3 and Model 4 ( $\beta=-0106$ in Model 1 and $\beta=-0316$ in model 4$)$. This implies that the venture capitaist's financial participation is negatively associated with cognitive contribution measured through 
putting at their disposal professional relations and the creation of investment opportunities.

In this context, Amblard and al. (2001), Parrish (2010), Dumenil and Levy (2011), Weinstein (2012) and Gerber and Hui (2013) have documented that it is necessary to overcome the conflictual dimension by substituting it with a cooperative dimension in the interaction between shareholders and managers. The cognitive dimension is used as a means where by new productive opportunities can be invented and coordination between the different company stakeholders can be further enhanced. In this context, MacMillan and al. (1998), Sapienza and Timmons (1989), Xian (2012) and Croce and Murtinu (2013) have proven that the venture capitalist's intervention in matters of managerial consultations, counseling and support is considered as some of their greatest contributions. In this same line of thought and on analyzing these investors' offered contributions, Wood and Wright (2010), Sapienza and al. (1994), Lamarche and al. (2012) and Rosenbush and al. (2013), have reached the same findings and admittedly proved the strategic role the venture capitalists could accord to the firm. Actually this role consists mainly in assisting the entrepreneur in devising a clear vision, in making decisions, thus, contributing in reformulating strategic concept and visions. In this sense, Trehan (2000), Siegel and al. (2011), Finet (2012), Lefebvre (2013) along with Bocquet and Mothe (2013) also found that capital investors may also guide strategic choices and could even influence the firm's investment policy. Hence, through our achieved results, we have managed to the venture capitalist's contribution in firm management and active participation in its development. Noteworthy, however, on extending the venture capitalist's scope of intervention and contribution towards expanding the business, sustaining growth, then, taking greater risk, a rather negative contribution to the activity dynamism has been discovered, as measured through both of independent variables "Inv-Opp" and "Prof-Relation". At this level, it appears well that the venture capitalists, subject of our sample prove to be, somewhat risk averse; they seem, rather satisfied with transferring knowledge and skills, owing to their experience, various relations and contacts in this particular area.

Regarding the control variables, the variable "Share_E" coefficient in Model 1proves to be positive and significant at the threshold of $5 \%(\beta=0.063)$. This implies that the entrepreneur's financial participation turns out to have a positive and significant effect on the cognitive contribution, the venture capitalist can accord to the firm. This achieved also corroborates those published by MacMillan (1997) Deferges (2011) and Solignac (2011). Yet, some elaborated work, (Desbrières, 2005; Sonsoy, 2008; Pluchart 2008 and 2010) have shown that the venture capitalist seems less motivated to set up a process of transfer and exchange of expertise and knowledge with the entrepreneur once the latter, appears to significantly important have financial contribution and interests. In this respect, and on treating corporate governance of venture capital funded firms, mechanisms, some previously conducted works (Sapienza, 1989; Leete and al., 2013; Armstrong and al., 2014; Bocken et al., 2014) have found that the venture capitalists' participation appears to lead,conversely, to a reduction in the managers' detained, capital share, in such a way as the venture capitalists would, more or less take part in the company management affairs and exercise their power in terms of their relative detained proportion of shares. Involvement within the company and participation in elaboration strategy and management also highly depend on the venture capitalist's financial power in respect of that of the entrepreneur. His remarkable majority participation denotes well financial investments together with an investment of time, favorizing an effective accompaniment of the entrepreneur through knowledge sharing, advice and help, for the sake of to identifying good investment opportunities. Nevertheless, should his financial interests prove to be too low, he, then, would not be necessarily motivated to jointly construct with the entrepreneur an apprenticeship likely to process be costly in terms of transfer time and difficulties.

In Model 3, the regression coefficient relevant to the control variable "stage" seems negative and significant at the threshold of 5\% $(\beta=-0,511)$. This implies that the cognitive contribution of the venture capitalist turns out to be negatively associated with the firm's development stage. At an early development stage, the firm appears to have a low knowledge reserve in relation to capital investors, who are generally more experienced. This asymmetrical distribution of knowledge helps create a divergent discrepancy among the different mental models schemes and strategic visions themselves. Several previously conducted studies (Barney and al., 1989; George and al., 2011; Amess and wright, 2012 and Bocken and al. 2014) have stated that at a less advanced development stage, the firm appears to display a high costs of transfer from the parts of capital investor to the entrepreneur, in terms of time and integration difficulty. Indeed, Knowledge transfer would be more difficult in case of a mature entreprise.

In the same model, the regression coefficient of the control variable "Exp_VC" appears to be positive and significant at the threshold of $10 \%(\beta=0.091)$. Suggesting that the venture capitalist's cognitive contribution is positively related with the experience business level. The more experienced a venture capitalist is, the more knowledge and skills he will have in terms of valuation of projects, market and investment opportunities (Stromberg 2007, Lerner and al., 2012 and Bocken and al., 2014).In addition, with the important contacts, he has enjoy more superior skills in relation to the entrepreneur, which is likely to allow him to allocate the firm a competitive advantage and even the advantage of the IPO as output mode (Gottschalg and al., 2004; Davis and al., 2011; Bacon and al., 2013 and Appelbaum and al., 2013).

Still with the same model, the regression coefficient related to the control variable "Syndication" sounds to be positive and significant at the threshold of $10 \%(\beta=0.556)$. This implies well that the cognitive contribution of venture capital is positively related with the different investors' financial participation syndication. According to studies conducted by Lockett and Wright (1999), information and knowledge sharing would constitute the major reasons lying behind syndication. Further to the financial argument defining syndication, some previously conducted works have justified the appeal tosyndication within a cognitive context, suggesting that, in addition to financial means, venture capitalists also bring in cognitive resources in terms of knowledge and skills (Manigart and al., 2006; Wrigt and Lockett 2002; Weber and Kratzer, 2013). They have demonstrated that the syndicated investor supported firms have greater opportunity to be introduced in the stock market, enjoy better valuation of shares on the market and record better performance (Tian( 2008)).

With respect to Model 4, the regression coefficient of the control variable "Bq _Aff" proves to be negative and significant at the threshold of $10 \%(\beta=-0,907)$. This implies that the venture capitalist's cognitive contribution seems to be negatively associated with the venture capital organism's banking affiliate. Some previously works conducted have shown that the venture capitalists' ownership structure appears to have noticeable influence on the relationship with the funded company, (Gompers and Learner, 2004; Maula and al., 2004 and Bacon and al., 2013). They have established a distinction between the an independent investors and the affiliated capital-ones, on the basis of their greater incentive to transfer knowledge to the funded firm, furthermore, they have demonstrated that firms financed by such investors would certainly enjoy greater financial, strategic and stock-market profitability. Besides, they have also noticed that group affiliated capital investors would be primarily interested in maximizing their proposes profitability for a given risk level, while the independent capital investors would target objectives other than the investment financial performance, namely, the transfer of knowledge to the financed firm (Ginsberg and al., 2005; Bottazi and al., 2007, and Puri, 2008).In the same model, the regression coefficient of the control variable "Exp_VC", turns out to be positive and significant at the threshold of $1 \%(\beta=1.141)$. This implies that the venture capitalist's cognitive contribution has been positively linked with the experience level in the venture capital area. Similarly, the regression coefficient of the control variable "Syndication" appears to be positive and significant at the threshold of $10 \%(\beta=0.606)$, denoting that the venture capitalist's cognitive contribution is 
positively associated with the financial participations' syndication. This very result has already been proven in the model 3 introduced regressions.

On the basis of the already mentioned observations, one might well note venture capital capitalist organism's participation has exceeded the role of just a financial- resource provider to an active investor throughout the investment period. Noteworthy, however, is that the companies benefiting from the presence of the financial intermediary turn out to be are non-listed ones, which makes the information uncertainty risk, as well as the executive's deviant behavior, stand as critically crucial factors. Consequently, the venture capital firm would sound as remarkably responsible and their involvement in the company's management affairs should appear to be rather strong. Most often, an investor of this typeenjoys a noticeably high professional competence level, owing to the experience they have acquired through dealing with different companies, enabling then to provide valuable assistance and enrichment in matters of effective company strategy promotion along witha more efficient handling and assessment of the market the continuously undergoing changes. So costly as knowledge transfer and experience exchange might be, one could still note, clearly that the venture capitalists presence is usually accompanied with valuable cognitive inputs. As a matter of fact, such a towards the company is supposed to compensate for the company's contracting capital out put through the creation of more profitably precious added value and according the company with a rather competitive advantage likely to help it get introduced in the stock market as an IPO.

It is also worth highlighting, in this respect, that on collecting data, it has been noticed that the presence of venture capital participation is often accompanied with other types of investors who, thanks to their experiences, prove to help in promoting the to guidance and advisory capacity, through, mostly, to a little extent. The syndication and coordinating of such skills and competences prove to help maintain ensure and facilitate the transfer of information and strategic guidance as factors elements necessary for reaching the achievement of significant added value to the company's capital the output and the introduction IPO as a major output mode.

Based on such findings, one might well consider that venture capitalist's presence in the contracting company's capital shall, by no means, constitute a crucial source of valuable cognitive gains and benefits for the latter.

Noteworthy, however, is that on extending the venture capitalist's scope of intervention and cognitive contribution company's operations' activity dynamism, therefore, towards assuming greater risk (models 3 and 4); the venture capitalist's financial participation impact on the cognitive contribution turns out to be negative. This fact, finding denotes well that the subject of the sample, appear to be risk averse and contended wish focusing mainly on the transfer of knowledge and skills owing to the experience they enjoy in matters of relevantspecially trade. Hence, theachieved cognitive contribution would often appear to be too limited. Such a result might well have its explanation the fact that most of the Tunisian venture capitalists turn out to be affiliated to the banking institutions. As a result, their investment strategies along with theand the nature of their contributions offered to the funded company, would, therefor, tend to be rather dependent on the parent company's devised strategy, i.e., that of the " bank ".

\section{Conclusion}

In the basis of our achieved results, one could well notice that the venture capitalist has exceeded the role of a financial resources raiser to that of an active investor throughout the investment period. The companies taking advantage of such a presence are usually non-listed firms, which makes the risk of information uncertainty and executive's deviant behavior crucially important.Therefore, the venture should prove to be highly responsible, with a rather effectively strong involvement in the company's affairs' manage- ment. This type of investors is most often characterized with a high professional-competence level, due to their experience in a wide array of firms, enabling them to provide effective corporate assistance, useful for the property and enrichment development of the funded firm, in such away as better treat and assess the market witnessed this commitment with regard to the firm is supposed to reward the release of the firm capital by creating significant added value and offers the company a further competitive advantage which likely to help favorize the possibility of an IPO for the funded firm. In effect, one could well consider that the presence of the venture capitalist in the firm's capital constitutes a source of cognitive gains for it. Still these gains can be restrained by a well determined risk level. Based on the results attained, it appears well that gains achieved seem to depend highly on the nature of cognitive contribution the venture capitalist is aiming to implement and achieve. The determination and setting of such an intervention can well have its explanation either in the very nature of the venture capitalist, or in the investment strategy adopted. To note, most of the venture capitalists who have funded or formed our sample have been affiliated with a bank. Consequently, their investment strategy and the nature of their contributions to the company would then seem to be highly dependent on those of the parent company "the bank" so identification of any investment projects will be predominantly determined by the already set or adopted strategy. In addition the goals achieving vision or policy should coincide harmoniously with those defined by the parent company. As a matter of fact, most of the undertaken investment projects appear to be carried out particularly with such customers, by trying to fund and satisfy its customers investment needs, who most often demand fund injection either for growth purposes or for restricting and rehabilitation innovative programs.

\section{References}

[1] Alexander P. and Peter R. (2013): "Venture capital and new business creation", Journal of Banking and Finance, Vol.37 No.12, pp. 4695-4710.http://dx.doi.org/10.1016/j.jbankfin.2013.08.010

[2] Allen F. and Song W.L. (2002): "Venture capital and corporate governance", working paper.

[3] Amess K. and Wright M. (2012): "Leveraged buyouts, private equity and jobs", Small Business Economics, Vol. 38 No.4, pp. 419430.http://dx.doi.org/10.1007/s11187-010-9280-9.

[4] Arthus D. J. and Busenitz L. W. (2002): "Theorical foundations of venture capitalist: current issues and futures direction's, working Paper.

[5] Axelson U., Stromberg P and Weisbach M. (2009): "Why are buyout levered, the financial structure of private equity funds", Journal of Finance, Vol.64 No.4, pp.15491582.http://dx.doi.org/10.1111/j.1540-6261.2009.01473.x.

[6] Axelson U., Stromberg P. and Weisbach M. (2009): "Why are buyout levered, the financial structure of private equity funds", Journal of Finance, Vol.64 No.4, pp. 15491582.http://dx.doi.org/10.1111/j.1540-6261.2009.01473.x.

[7] Bacon N., Wright M. Meuleman M. and Scholes L. (2012): "The impact of Private equity on management practices in european buyouts: short-termism, Anglo-Saxon, or host country effects? Industrial Relations" Journal of Economy and Society, Vol.51 No. 1, pp. 605-626.

[8] Bacon N., Wright M., Meuleman M. and Scholes L. (2012): "The impact of Private equity on management practices in European buyouts: short-termism, anglo-saxon, or host country effects?,Industriel Relations", Journal of Economy and Society, Vol.51No.1, pp . 605-626.

[9] Barney J.B. Busenitz L.W., Fiet JO and Moesel DD. (1996): "New venture teams' assessment of learning assistance from venture capital firms", Journal of Business Venturing, Vol.11, pp. $257-$ 272.http://dx.doi.org/10.1016/0883-9026(95)00011-9.

[10] Barney J.B., Busenitz L.W., Moesel D. D. and Fiet J. O. (1994): "The relationship between venture capital and managers in new firms: determinants of contractual covenants", Managerial Finance, Vol.20.http://dx.doi.org/10.1108/eb018457.

[11] Becher D.A. and Frye M.B. (2011): "Deos regulation substitute or complement governance?"Journal of Banking and Finance, Vol.35 No 3 http://dx.doi.org/10.1016/j.jbankfin.2010.09.003. 
[12] Bechman C., Burton M.D. and O'Reilly C. (2007): "Early teams: the impact of team technology on VC financing and going public", Journal of Business Venturing, Vol.22 No.2, pp. 147173.http://dx.doi.org/10.1016/j.jbusvent.2006.02.001.

[13] Bergemann D. and Hedge U. (1998): "Venture capital financing, moral hasard, and learning", Journal of Banking and Finance, Vol.22, 4266(98)00017-X

[14] Berry T. and Junkus J. (2013): "Socially responsible investing: an investor perspective", Journal Business.Ethics, Vol.112 No.4, pp.707-720.http://dx.doi.org/10.1007/s10551-012-1567-0.

[15] Bocken N., Short S., Rana P. and Evans S. (2014): "A value mapping tool for sustainable business modeling", Corporate Governance, Vol.213 No.5, pp. 482-497

[16] Bottazi L., Da Rin M. and Hellmann T. (2008): "Who are the active investors? Evidence from venture capital", Journal of Financial Economics, Vol.89, 512http://dx.doi.org/10.1016/i.jifineco.2007.09.003

[17] Bottazi L., Da Rin M. and Hellmann T. (2008): "Who are the active investors? Evidence from venture capital", Journal of Financial Economics,

Vol.89 512.http://dx.doi.org/10.1016/j.jfineco.2007.09.003

[18] Brander J., Amit R. and Antweiter W. (1998): "Venture capital syndication: improved venture selection and value-added hypothesis", Discussion paper, university of British Columbia.

[19] Burmeister K. and Schade C. (2007): "Are entrepreneurs decisions more biased? An experimental investigation of susceptibility to status quo bias", Journal of business Venturing, Vol.22 No.3, pp. 340 362.http://dx.doi.org/10.1016/j.jbusvent.2006.04.002.

[20] Bygrave W. and Timmons (1992): "The CEO, venture capitalists and the board", Journal of Business Venturing, Vol.8, pp.99-113.

[21] Chan Y., Siegel D. and Thakor A.V. (1990): "Learning, corporate control and performance requirements in venture capital contracts", International Economic Review, Vol. 31No.2, pp. 365-381.

[22] Cortez M.C., Silva F. and Areal N. (2012): "Socially responsible investing in the global market, the performance of US and European Funds", International Journal of Finance and Economic, Vol.17 No.3, pp. 254-271.http://dx.doi.org/10.1002/ijfe.454.

[23] Croce A. Marti J. and Murtinu S. (2013): "The impact of venture capital on the productivity growth of European entrepreneurial firms: screening or value added effect?"Journal of Business Venturing, Vol.28, 510.http://dx.doi.org/10.1016/j.jbusvent.2012.06.001

[24] De Clerq D. and Sapienza H.J. (2001), "The creation of relational rents in venture capitalist-entrepreneur Dyads, Venture capital", International Journal Entrepreneurial Finance, Vol.3 No.2, pp.107127.http://dx.doi.org/10.1080/13691060110045661.

[25] Dimov D. and Milanov H. (2009): "The interplay of need and opportunity in venture capital investment syndication", Journal of Business Venturing, Vol.25 No.4, pp.331348.http://dx.doi.org/10.1016/j.jbusvent.2009.01.002.

[26] Dimov D. etMilanov H. (2009): "The interplay of need and opportunity in venture capital investment syndication", Journal of Business Venturing, Vol.25 No.4, pp.331348http://dx.doi.org/10.1016/j.jbusvent.2009.01.002.

[27] Dimov D., Shepherd D.A. and Sutcliffe K.M. (2007): "Requisite expertise, firm reputation and status in venture capital investmen allocation decision", Journal of Business Venturing, Vol.22, pp.481-502.http://dx.doi.org/10.1016/j.jbusvent.2006.05.001.

[28] Engel D. and Keilbach M. (2007): "Firm-level implications of early stage venture capital investment and empirical investigation, Journal of Empirical Finance, Vol.14, pp.150-167. http://dx.doi.org/10.1016/i.jempfin.2006.03.004

[29] Fernandes N. (2008): "Board compensation and firm performance: the role of independent board members", Journal of Multinational Financial Management, Vol.78 No.1, pp.30 44.http://dx.doi.org/10.1016/j.mulfin.2007.02.003.

[30] Gerber E. and Hui J. (2013): "Crowd funding: motivations and deterrents for participation", ACM transactions on computing human interaction, Vol.20 No.6, pp. 32.http://dx.doi.org/10.1145/2530540.

[31] Guillaume A. and Alexander P.G. (2012): "Entrepreneurs' financing choice between independent and banking-affiliate venture capital firms", Journal of Corporate Finance, Vol.18 No.5, pp. 11431167http://dx.doi.org/10.1016/j.jcorpfin.2012.07.001.

[32] Hege U., Palomino F. and Schwienbacher A. (2009): "Venture Capital Performance: the disparity between Europe and the United States", Journal of Finance, Vol.30 No.1, pp.7-50.

[33] Higashide H. and Bireley S. (2002): "The consequence of conflicts between the venture capitalist and the entrepreneurial team in the United Kingdom from the perspective of the venture capitalist",
Journal of Business Venturing, Vol.17, pp.5981.http://dx.doi.org/10.1016/S0883-9026(00)00057-4

[34] Jengfang Ch., Woody M. and Chiachi Lu (2012): "The effects of public venture capital investments on corporate governance: evidence from IPO Firms in emerging market", Journal of Accounting Finance and Business Studies, Vol.48 No.1.

[35] Jennifer J.R., Henock L. and Dahlia R. (2009): "Managers and investors: responses to media exposure of board ineffectiveness", Journal of Financial and Quantitative Analysis, Vol.44 No.3, pp.579-605.http://dx.doi.org/10.1017/S0022109009990044.

[36] Lamarche T. and Rubinstein M. (2012): "Dynamics of corporate social responsibility: towards a new conception of control?"Journal of Institutional Economics, Vol.8 No.2.http://dx.doi.org/10.1017/S174413741100049X.

[37] Learner J., Leamon A. and Garcia-Robles S. (2014): “Adding value through venture capital in Latin America and the Carribean", working paper.

[38] Leete S., Xu J. and Wheeler D. (2013): "Investment barriers and incentive for marine renewable energy in the UK: an analysis of investor preferences", Energy policy, Vol.60, pp.866875.http://dx.doi.org/10.1016/i.enpol.2013.05.011.

[39] Marcus A., Malen J. and Ellis S. (2013): "The promise and pitfalls of venture capital as an asset class for clean energy investment", Organisation. Environnemental. Vol.26 No.1, pp. 31-60.

[40] Murphy K.J. and Sandino T. (2010): "Executive pay and independent compensation consultants", Journal of Accounting and Economics, Vol.49 No.3, pp.247262.http://dx.doi.org/10.1016/j.jacceco.2009.12.001.

[41] Rosenbush N. Brinkmann J. and Muller V. (2013): "Does acquiring venture capital pay off for funded firms? A meta analysis on the relationship between venture capital investment and funded firm financial performance", Journal of Business venturing, Vol.28, pp.335-353.http://dx.doi.org/10.1016/j.jbusvent.2012.04.002.

[42] Sheen Albert W. and Shai B. (2014): "The operational consequences of Private Equity Buyouts: Evidence from the restaurant industry", Working paper.

[43] Siegel D., Wright M. and Filatotchev I. (2011): "Private equity, LBOs and corporate governance: international evidence", Corporate Governance: An International Review, Vol.19 No.3, pp.186194 http://dx.doi.org/10.1111/j.1467-8683.2010.00842.x.

[44] Tian X. (2012): "The role of venture capital syndication in value creation for entrepreneurial firms", Review of Finance, Vol.16, pp.245-283.http://dx.doi.org/10.1093/rof/rfr019.

[45] Weber C. and Kratzer J. (2013): "Social entrepreneurship, social network and social entrepreneurs", International Journal of Entrepreneurs venturing, Vol.5 No.3, pp. 217-239.

[46] Weinstein O. (2012): "Firm, property and governance: from Berle and Means to the agency theory and beyond", Accounting Economics and Law, Vol.2 No.2.

[47] Wilson N., Wright M., Siegel D.S. and Scholes L. (2012): "Private equity portfolio company performance during the global recession", Journal of Corporate Finance, Vol.18 No.1, pp.193205.http://dx.doi.org/10.1016/j.jcorpfin.2011.11.008.

[48] Wirtz P. (2011): "The cognitive dimension of corporate governance in fast growing entrepreneurial firms", European Management Journal, Vol.29 No.6, pp.431447.http://dx.doi.org/10.1016/j.emj.2011.06.004. 